\title{
Knowledge Points and Research Perspectives on Detarium Senegalense, A Vulnerable Species in Benin
}

\author{
Benjamin A.K. Dossa*, Christine Ouinsavi, Towanou Houetchegnon, Bienvenue N. Sourou \\ Laboratoire d'Etudes et de Recherches Forestières (LERF), Faculté d'Agronomie, Université de Parakou, \\ Parakou, Bénin
}

*Corresponding Author: Benjamin A.K. Dossa, Laboratoire d'Etudes et de Recherches Forestières (LERF), Faculté d'Agronomie, Université de Parakou, Parakou, Bénin

\begin{abstract}
Detarium senegalense is a priority fruit species exploited but little known and under-valued in West African countries. The purpose of this study on the bibliographic synthesis is to take stock of the various works and aspects addressed on the species in order to highlight the lines of research that are still new for better enhancement of the species. The methodology used consisted of doing research on the net using some search engines such as google, google scholar, AGORA and some links by introducing more authentic keywords. Documents, such as articles, books, theses and dissertations on this species or not obtained online and in libraries were consulted and downloaded. It is appropriate after reading and analysis of the documents obtained that $D$. senegalense is a species having multiple uses in several fields. The fruits of the species are composed of important nutrients and very rich in vitamin $\mathrm{C}$ being indispensable in the food of the rural as urban populations. Several organs of the species are used in traditional medicine, the manufacture of cosmetics and pharmaceuticals. For further recovery and conservation of the species, additional studies are relevant to the conservation status and impact of exploitation on D. senegalense populations in Benin.
\end{abstract}

Keywords: Fruit species, non-timber forest products, literary review, D. senegalense

\section{INTRODUCTION}

The forest represents a vast area of space where huge terrestrial species survive (trees, animals) which allow the population to provide for their needs through services (energy, medicine, food) which they render to the latter, know the fight against poverty, food security and environmental protection (FAO, 2012). To provide for his basic needs (food, care, clothing), man has developed essential and elementary knowledge of nature. This form of knowledge has enabled man to achieve a domination of empirical techniques and a certain knowledge of natural resources (Home, 2009). This process linked to the use of natural resources will therefore generate a body of knowledge and know-how which have made it possible to develop practices and representations based on an empirical representation of nature.

The scientific world and the international community have lingered on agreeing to the reality of knowledge and know-how that is expressed through the local uses of forest resources among indigenous peoples (Sabaly, 2014). In African countries and in a special way in Senegal, forest trees and especially fruit trees are increasingly important and essential, because they ensure food security for populations and especially rural ones (Diop, 2013). The rural populations of the Guinean savannas in Ivory Coast consume many wild fruits from the forests (Ambé, 2000). However, there is a large trade in some fruits from the forest, and sometimes most of them are eaten raw at the picking sites. Several fruit forest species are spared during the clearings because of their economic interests. However, others are destroyed in favor of more profitable and economical crops.

Many fruit species have been discovered in several forests in Africa. Among them, the fruits of others are regularly consumed by the rural population as well as urban and others less known, therefore little consumed (Ambé, 2000). In Benin, several wild fruits remain unknown or less exploited by the local population, despite their importance and their richness in Vitamin C. It was concluded that the development of these resources could be beneficial to the populations concerned. Among these species, figure $D$. senegalense which is a species of the family Caesalpiniaceae which produces globular fruits (Adenkunle et al., 2011) and is commonly called tallow tree, large detar. It is a dicotyledonous angiosperm that grows from thick and scattered branches and can reach $40 \mathrm{~m}$ in height and then 60 to 
$100 \mathrm{~cm}$ in crown crowns (Adenkunle et al., 2011). This plant is multipurpose which, along with the production of nutritious fruits (El-Kamali, 2011) is also used for medicinal purposes (Cissé et al., 2010) and quality wood (https: //fr.wikipedia. org / wiki / Detarium_senegalense). They produce globular drupe fruits which are characterized by their dark green coating, fibrous paste (El-Kamali, 2011). In Senegal, D. senegalense J. F. Gmel is one of the most important forest fruit species in the logging economy (Diop et al., 2010). It grows wild in Casamance and the Sine-Saloum Islands. In the subregion, it is found in Gambia, in both Guinea, in Nigeria, in Mali.

In some West African countries representing the geographic distribution of D. senegalense, and playing many important roles, several scientific data or information are lacking on the species and can contribute more to its knowledge and its development. . The present study makes the inventory and the bibliographical synthesis of $D$. senegalense, a priority and economic species by approaching the aspects related to taxonomy, botany, origin, ecology, phenology, geographic distribution and socio-economic importance and will lead to new lines of research which will contribute to better conservation and sustainable exploitation of the species.

\section{Data Collection AND Analysis Protocol}

The very first work carried out at the beginning of this document consisted in doing documentary searches very first on the net by introducing some keywords in the search engines Google, Google Scholar, AGORA and the use of some links like: https: //tel.archives-ouvertes.fr/ and https://uses.plantnet-project.org/fr/Detarium_senegalense_(PROTA).The main keywords used to search for information in each of the search engines and links above are: Detarium senegalense, importance of Detarium senegalense, uses of Detarium senegalense, geographic distribution of Detarium senegalense, ecology of Detarium senegalense, uses of Detarium senegalense in traditional medicine, pharmacognosy of Detarium senegalense, food use of Detarium senegalense, Detarium senegalense + Detarium microcarpum, At the end of this research, several documents were identified at the start including around 351. This result was the first phase of our research. A summary and indepth analysis of all the first documents identified made it possible to take into account the documents and publications obtained using the keyword "Detarium senegalense" in the various search engines used and especially that of "Google scholar". Documents mentioning the different areas of use and importance of Detarium senegalense obtained on this search engine. Regarding the documents talking about the description of D. senegalense were obtained typing one typing one of the keywords listed on "google ". Among all these documents identified during the documentary searches, all the documents having free access and considered interesting were downloaded and taken into account in the data analysis. With regard to publications that do not have free access, the links http://sci-hub.la/ and http://gen.lib.rus.ec were used to consult their databases in order to download these articles. Likewise, the AGORA database was also consulted using the institutional access code and member of the university of belonging. All documents and publications containing 'Detarium senegalense' 'in the AGORA database have also been downloaded and are structured for inclusion in the manuscript. A total of 53 documents (theses, articles and dissertations) deemed relevant and speaking of D. senegalense and its importance were used in the context of the bibliographical synthesis. The silent reading of these documents made it possible to identify and have several information, namely its origin, its ecology, its geographic distribution, its botanical description, its phenology, its local appellations, its fields of use and importance on D. senegalense

\section{ORIGin, ECOlogy ANd Geographic Distribution OF D. SENEGALENSE}

Of tropical African origin, D. senegalense JF Gmel., Is a forest species which was first described in 1789, under the name of "Detar" of Senegal by De Jussieu in the Genera Plantarum (Cavin , 2007; Diop et al., 2010). D. senegalense is a species of forest galleries and dense humid forests (Akoègninou et al., 2006; Cavin, 2007; Neuenschwander et al., 2011). It is sometimes found in agrosystems and in humid lowlands and cool soils. D. senegalense is most commonly encountered along streams. D. senegalense spreads from Senegal and The Gambia and spreads to Sudan, and south to the north of the Democratic Republic of Congo (Akoègninou et al., 2006; Diop et al., 2010). In the Caribbean region, where this species is widespread, it is planted as a fruit tree and ornamental shade tree. According to the same author, D. senegalense is distributed in Africa, on the edges of the dense humid forest, in the coastal regions and in the northern regions of Côte d'Ivoire and thus penetrates into the Sudano-Guinean zone, from Sudan, Guinea Conakry, to Central Africa. The species is also present in Gambia, Guinea, Sierra 
Leone, Liberia, Ivory Coast, Ghana, Nigeria, Cameroon, Central African Republic, Mozambique and in Benin (Arbonnier, 2002; Akoègninou et al., 2006; Diop et al., 2010). The D. senegalense species is more and more found in the Guinean-Congolese tropical rainforest where the rainfall is higher than in the Sudano-Guinean zone.In Senegal, it is particularly the regions of Ziguinchor and Fatick (Sine and Saloum islands) which currently constitute the main production areas for D. senegalense. It is present in the western part of the Sahelo-Sudanian climate characterized by a climate of the trade winds with an average annual temperature of $26-31^{\circ} \mathrm{C}$. It is a dry climate with considerable variations in humidity. The rainy season lasts 2 to 4 months with a maximum of precipitation during the month of August for an annual average of 400 to $1200 \mathrm{~mm}$. This climate is characteristic of the coast of Senegal, the Gambia, Lower Casamance and Guinea-Bissau. The species is found in the western part of the Sudano-Guinean climate with an average annual temperature of $24-28^{\circ} \mathrm{C}$ and an average annual rainfall of 950 to 1750 $\mathrm{mm}$. In Benin, this species is found in the Guinean zone and in the Sudano-Guinean zone and in the phytogeographic Districts of Pobè, Bassila, Dogo, Bantè, Tui, Kilibo and Djougou (Neuenschwander et al., 2011). Figure 1 below shows the geographic distribution of $D$. senegalense in Africa.

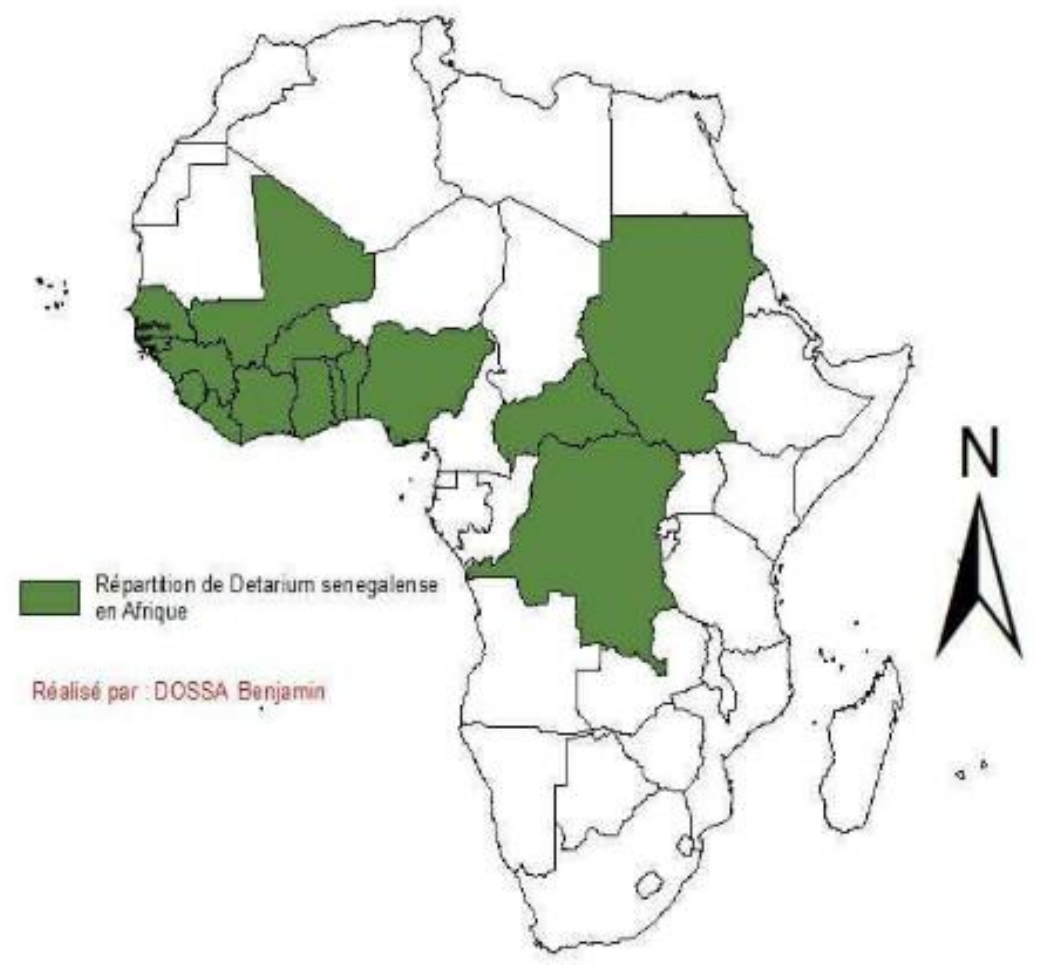

Figure1. Geographic distribution of D. senegalense in Africa

\section{Presentation of D. Senegalense J.F.Gmel: the Ditax}

D. senegalense is a large tree up to 15 to $30 \mathrm{~m}$ tall (Figure 2.a) and sometimes $40 \mathrm{~m}$ in forest galleries. Its crown is dense and hemispherical, its branches are stocky and spread out (Akoègninou et al., 2006; Cavin, 2007) (Figure 3.a and b). The bole is straight and the bark is thick, greyish sometimes bluish, slightly cracked and scaly in large trees (Figure 2.a and b). The bole is sometimes devoid of branches over a height of 12 to $15 \mathrm{~m}$, straight or irregular, cylindrical, up to 60 to $100 \mathrm{~cm}$ in diameter, without buttresses but sometimes thickened at the base (http: //uses.plantnet-prject .org / en / Detarium_senegalense_(PROTA)). The leaves are composed paripinnate with 5 to 6 pairs of opposite leaflets arranged alternately (Figure 4.a). The leaflets are 4 to $6 \mathrm{~cm}$ long and 3 to $4 \mathrm{~cm}$ wide, oval to elliptical, rounded at the ends and emarginate at the top. The limb is thin, flexible, finely leathery, pinnate and green on the underside. The inflorescence is in more or less branched axillary panicle and 5 to $8 \mathrm{~cm}$ long. The creamy white flowers, in raceme, have a glabrous or glabrescent calyx. They have four elliptical sepals with an ovoid and pubescent ovary, and ten white bilocular stamens. The fruit has a globular to ovoid shape 4 to $6 \mathrm{~cm}$ in diameter, rounded (Figure 4.a and b). The fruit is smooth and greenish, eventually becoming blackish, with greenish pulp and very fibrous. The fruit has a nucleus up to $4.5 \mathrm{~cm}$ in diameter and contains a single seed (Figure 4.c). Inside the seed is the flattened fine (Figure 4.d) and oilseed which is much more commercialized and in particular in Benin Neuenschwander et al. (2011). 


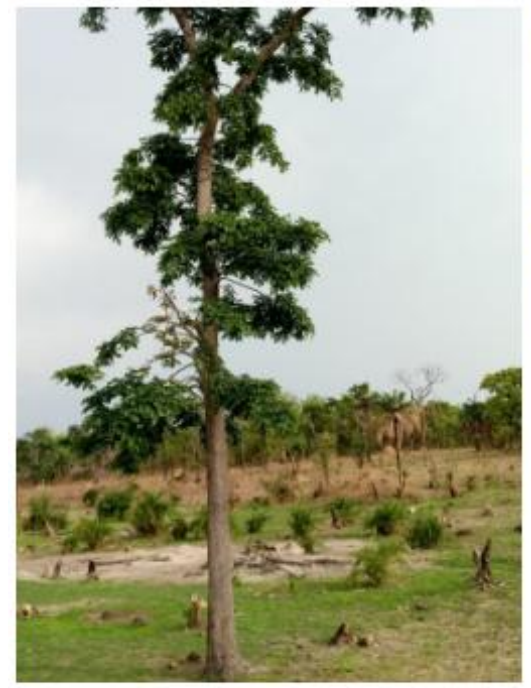

a

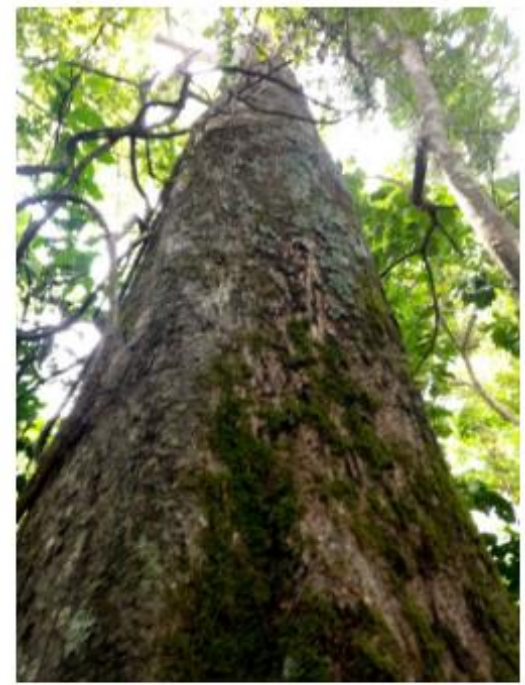

b

Figure2. Overview and trunk of D. senegalense
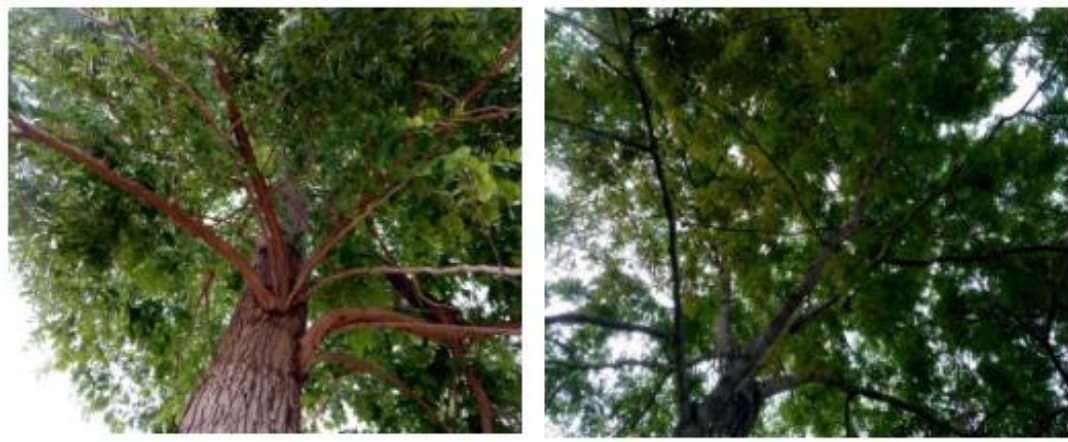

Figure3. Foliage of D. senegalense in Wéllan and in the classified forest of Bassila (Source: Dossa, March 2018)

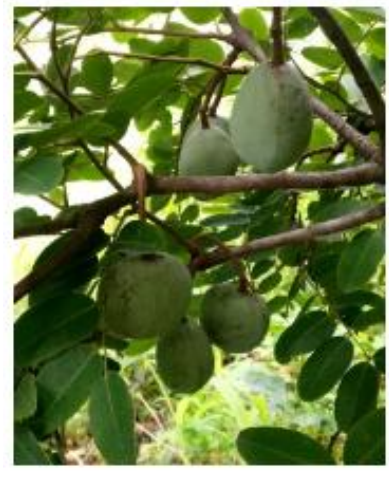

a

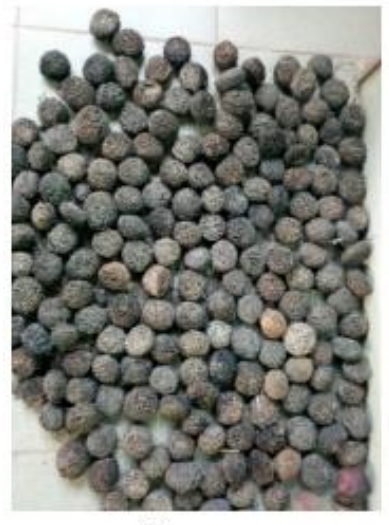

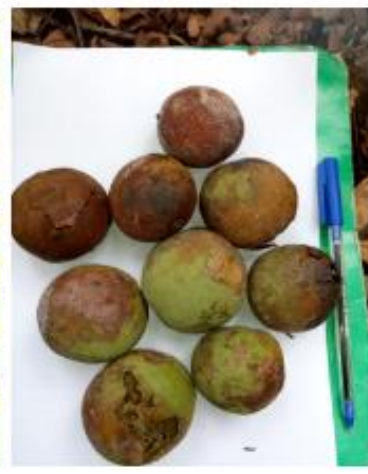

b

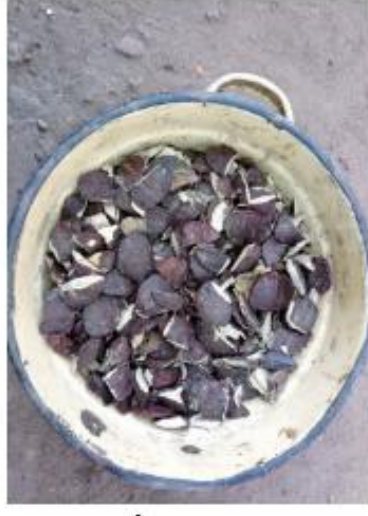

Figure4. Various organs of D. senegalense (immature leaves and fruits $(\boldsymbol{a})$, mature fruits $(\boldsymbol{b})$, seeds $(\boldsymbol{c})$, harvested almonds (d)) (Source: Dossa, 2018) 


\subsection{Phenology}

In Benin, the fruiting period of the species is from March to May. Variability in the fruiting period has also been observed as a function of Benin's climatic gradients. In the classified forest of Bassila and riverside village, the fruiting period of the species already ends from March. While in the Monts-Kouffè classified forest, the fruiting period of $D$. senegalense extends until June.

\subsection{Taxonomy of $D$. Senegalense}

D. senegalense JF Gmel is a species belonging to the spermaphytes branch, the Angiosperms subbranch, the Dicotyledons class, the Dialypetales sub-class, the Caliciflores series, the Rosales order, the suborder Fabaceae (formerly Legumes), the Family Caesalpiniaceae and the Genus Detarium Juss (Cavin, 2007; Diop et al., 2010; Akoègninou et al., 2006). It is represented by three taxa including Detarium microcarpum, Detarium heudelotianum (toxic form and fruit) and $D$. senegalense (Akoègninou et al., 2006; Cavin, 2007).

\subsection{Chemical Property of the Organs of the Species}

Several studies have been carried out on the importance of the chemical properties of $D$. senegalense. The very first biochemical works on the fruits of ditax also called $D$. senegalense were carried out by Sambuc (1887). Auffret (1948), noted the presence of a vitamin C content of 2 g. $100 \mathrm{~g}-1$ of pulp. These results thus made it possible to classify ditax among the picking fruits richest in vitamin C. Toury et al., (1967) in their work also found $1290 \mathrm{mg}$ of vitamin C. $100 \mathrm{~g}-1$ of the pulp. In general, the pulp of $D$. senegalense (ditax) is characterized by a high content of vitamin C greater than $1000 \mathrm{mg} .100 \mathrm{~g}-1$ of the fresh pulp. The vitamin $\mathrm{C}$ content is mainly prominent and contains 0.5 to $1 \%$. Kerharo and Adam (1974) carried out research on the primary metabolic composition of the fruit of D. senegalense, which makes the species a good nutritional quality. A study carried out on aroma compounds from the pulp of D. senegalense has revealed the presence of higher alcohols (methyl-butenol, pentenol, hexanol).An analysis carried out on the biometric characterization on the fruit and supplemented by a biochemical analysis of the pulp showed an acidity and higher contents of vitamin $\mathrm{C}$, pheophytin A and in saccahrose (Diop, 2012). The fruit is noticed by its green pulp very rich in vitamin C (more than $1 \mathrm{~g} \bullet 100 \mathrm{~g}-1$ ). It is a highly recognized fruit which is widely consumed in Senegal mainly in the form of a drink, marmalade, sorbet or fresh (Diop et al., 2010). The acidity of the fruit is relatively low (0.16 mEq. 100 g-1).

\subsection{Names, Uses and Importance of $D$. Senegalense}

D. senegalense takes different names in different languages in the countries where it is known and used as an economic good and a fight against food security. In the study environment in Benin, the different local populations do not have a very good knowledge of $D$. senegalense. The species is most recognized by hunters in the different areas of this study. Some women have knowledge of the species following the collection and marketing of the fines of the species in the years from 2000 to 2010. Names are assigned to the species some are in languages at the local level (Benin) and international (Table 1).

Table1. Some vernacular names of D. senegalense

\begin{tabular}{|c|c|c|c|c|}
\hline Species & Language & Country & Names & Sources \\
\hline \multirow{5}{*}{ D. senegalense } & Fon & Bénin & Dakpa, dokpa; & $\begin{array}{c}\text { Neuenschwander } \text { et al, } \\
(2011)\end{array}$ \\
\cline { 2 - 5 } & Nango & Bénin & Guéténégbé Atou & \\
\cline { 2 - 5 } & Anii & Bénin & Ôlô Odo & $\begin{array}{c}\text { Neuenschwander } \text { et al, } \\
(2011)\end{array}$ \\
\cline { 2 - 5 } & Yoruba & Bénin & Ogbògbò & Diop et al.,(2010) \\
\cline { 2 - 5 } & French & - & Tallow tree, Large detar; & Tallow tree \\
\cline { 2 - 5 } & Anglais & - & Ditax ou ditakh & \\
\cline { 2 - 5 }
\end{tabular}

\section{IMPORTANCE OF D. SENEGALENSE}

\subsection{Medicinal Importance of $D$. Senegalense}

D. senegalense is a leading medicinal plant. Several parts of the plant are used in traditional medicine. A decoction or maceration of the bark is prescribed for major bleeding, digestive problems, bronchitis, pneumonia and upset stomach, and to expel the placenta after childbirth. The bark powder is applied to 
wounds, burns and skin conditions, while the bark pulp is used in the treatment of tuberculosis and as a tonic. The bark also serves as arrow poison, replaces soap and, added to palm wine, accelerates fermentation and enhances bitterness. A root decoction is prescribed as an analgesic and against intestinal disorders, slump, debility and anemia. A decoction of leaves and shoots treats fever, trypanosomiasis, dysentery, anemia, conjunctivitis, arthritis, inflammation, fractures, boils and skin conditions. The fruit pulp is applied to treat kidney pain, spinal tuberculosis, syphilis, cough, rheumatism and leprosy, and mixed with other fruits as a stimulant. The fruit also has therapeutic properties against cough, kidney ailments and leprosy. The seeds serve as an antidote to arrow poison and emetics, and the smoke from burning seeds of mosquito repellents. D. senegalense is planted as an ornamental shade tree. The edible form of $D$. senegalense has even more uses than D. microcarpum, both in traditional medicine and in home use. These uses are in the following table (Adam et al., 1991; Arbonnier, 2002; Cavin, 2007; Diop et al., 2010).

Table2. Medicinal use of D. senegalense

\begin{tabular}{|c|c|c|c|}
\hline Organs used & Diseases treated & Method of preparation & Country \\
\hline \multirow{5}{*}{ Fruit } & Leprosy & $\begin{array}{l}\text { Mixing ripe fruit with water until a semi-pasty } \\
\text { mass is obtained. The liquid exuded by } \\
\text { pressure from this magma is given as a drink, } \\
\text { while the remaining product is used in friction } \\
\text { all over the body. }\end{array}$ & Peul Toucouleur \\
\hline & Syphilis & $*$ & $*$ \\
\hline & $\begin{array}{c}\text { Colds, sore } \\
\text { throat, and chest } \\
\text { diseases }\end{array}$ & Fruit pulp & $*$ \\
\hline & $\begin{array}{c}\text { Tonic and } \\
\text { stimulating } \\
\text { during the trip }\end{array}$ & Fresh fruits & Northern Nigeria \\
\hline & $\begin{array}{l}\text { Chronic kidney } \\
\text { pain }\end{array}$ & Fruits used in local friction & $*$ \\
\hline \multirow[b]{3}{*}{ Seeds } & $\begin{array}{c}\text { Glucose level of } \\
\text { diabetics }\end{array}$ & $*$ & $*$ \\
\hline & $\begin{array}{l}\text { Snake bites and } \\
\text { poisoned arrows }\end{array}$ & Seed coat & Northern Nigeria \\
\hline & $\begin{array}{c}\text { Mosquito } \\
\text { repellent }\end{array}$ & Burnt seeds & Sénégal \\
\hline \multirow{7}{*}{ Leaves } & Constipation & Decoction, used as a drink or enema & * \\
\hline & Dysentery & Decoction, used as an enema or a potion & $\begin{array}{l}\text { Ivory Coast, } \\
\text { Upper Volta }\end{array}$ \\
\hline & $\begin{array}{l}\text { Action on the } \\
\text { intestine, } \\
\text { anorexia and } \\
\text { anemia }\end{array}$ & Different preparations & Sénégal \\
\hline & Fever & $\begin{array}{l}\text { Young leaves boiled and administered at the } \\
\text { same time as food }\end{array}$ & $\begin{array}{l}\text { Sierra Leone, } \\
\text { Nigéria }\end{array}$ \\
\hline & Conjunctivitis & Maceration used in eyewash & \\
\hline & Itching & Decoction used as a lotion & $\begin{array}{l}\text { Ivory Coast, } \\
\text { Upper Volta }\end{array}$ \\
\hline & Wounds & Sheets used as an occlusive dressing & $*$ \\
\hline \multirow[b]{5}{*}{ Bark } & Anemia & & \\
\hline & $\begin{array}{l}\text { Expulsion of the } \\
\text { placenta }\end{array}$ & Decoction given to women after childbirth & \\
\hline & Bronchites & & \\
\hline & $\begin{array}{l}\text { Severe stomach } \\
\text { aches: colic, } \\
\text { intestinal } \\
\text { obstruction }\end{array}$ & Decoction, given as a drink & $\begin{array}{l}\text { Diola of Basse- } \\
\text { Casamance }\end{array}$ \\
\hline & $\begin{array}{c}\text { Action on the } \\
\text { intestine, } \\
\text { anorexia, anemia }\end{array}$ & Different preparations & \\
\hline
\end{tabular}




\begin{tabular}{|c|c|c|c|}
\hline & $\begin{array}{l}\text { Relieves in case } \\
\text { of indigestion }\end{array}$ & Bark cooking water & \\
\hline & Tuberculosis & Bone administration & \\
\hline & Pneumonia & In association with other plants & $*$ \\
\hline & $\begin{array}{c}\text { Skin diseases: } \\
\text { leprosy, inflamed } \\
\text { buboes }\end{array}$ & Bark sprayed externally & Ivory Coast \\
\hline & $\begin{array}{c}\text { Medico-magic } \\
\text { treatment of } \\
\text { sleeping sickness }\end{array}$ & $\begin{array}{l}\text { Aqueous maceration in association with the } \\
\text { whole plant of Leptadenia hastat. Part of the } \\
\text { solution is given as a drink } 3 \text { times / day, } \\
\text { while the other part is used to wash the } \\
\text { patient. The macerate is used to massage it. }\end{array}$ & \\
\hline \multirow{3}{*}{ Root } & $\begin{array}{l}\text { Action on the } \\
\text { intestine, } \\
\text { anorexia and } \\
\text { anemia }\end{array}$ & $\begin{array}{l}\text { Different preparations and sometimes in } \\
\text { combination with the bark }\end{array}$ & Sénégal \\
\hline & $\begin{array}{l}\text { Strengthening in } \\
\text { weakness and } \\
\text { anemia }\end{array}$ & Concentrated infusion & $*$ \\
\hline & Analgesic & Cold infusion used in potion or washing & Gambie \\
\hline Whole plant & $\begin{array}{c}\text { Postpartum } \\
\text { hemostat }\end{array}$ & $*$ & Nigerian Igbo \\
\hline Wood & $\begin{array}{l}\text { Strengthening } \\
\text { weakness and } \\
\text { anemia }\end{array}$ & Concentrated infusion & $*$ \\
\hline
\end{tabular}

* Non précisé

Source: Cavin, 2007

\subsection{Importance of $D$. Senegalense in Terms of Food and Cosmetics}

The fruit pulp, greenish and sweet and sour, is edible and can be eaten raw or cooked. It could therefore contribute to food security, sustainable agriculture and rural development. It is also used to make sweets or ice cream. However, as it can also be toxic, caution should be exercised. The seeds are oilseed and edible, and when crushed are used as animal feed. In Nigeria, seed meal is traditionally used as a thickener in food (Wang et al., 1996). The gum flowing from the bark can be used to fumigate clothes and homes. We make glue with the roots and use the juice of the roots as a coating to pour the copper.The fruit is characterized by its green pulp very rich in vitamin C (more than $1 \mathrm{~g} \bullet 100 \mathrm{~g}-1$ ). It is a very popular fruit and widely consumed in Senegal mainly in the form of a drink, marmalade, sorbet or fresh (Diop et al., 2010). Some varieties of D. senegalense produce toxic fruits but the compounds responsible for the toxicity have not yet been fully identified. The fruits of $D$. senegalense were first described in 1789 by Antoine-Laurent de Jussieu in Senegal, under the name of "detar". They still play an important role in the cuisine and economy of this country today. No objective method for differentiating edible fruit from toxic fruit is currently available. Despite its nutritional and organoleptic potential, ditax remains under-exploited. Therefore, the complete biochemical characterization of the fruits, the evaluation of the technological potential, the development of methods for the rapid detection of toxic fruits and the improvement of the stability of products processed from ditax would be interesting research perspectives to better exploit this fruit rich in vitamin C. Analysis has revealed that D. senegalense seeds contain $24.43 \%$ carbohydrates, $7.23 \%$ protein, $31.16 \%$ fiber, $5.89 \%$ moisture and $1.93 \%$ ash. Analysis of the mineral content revealed the concentrations of potassium $(99.26 \mathrm{mg} / \mathrm{g})$, calcium $(71.11 \mathrm{mg} / \mathrm{g})$, magnesium $(77.83 \mathrm{mg} / \mathrm{g})$, sodium $(55.26 \mathrm{mg} / \mathrm{g})$, iron $(30.21 \mathrm{mg} / \mathrm{g})$, manganese $(7.89 \mathrm{mg} / \mathrm{g})$, zinc $(5.26 \mathrm{mg} / \mathrm{g})$ and copper $(4.29 \mathrm{mg} / \mathrm{g})$ (Sowemimo et al., 2011). These results show the nutritional value of $D$. senegalense seeds and justify its use in the traditional treatment of skin diseases. The oil extracted from almonds from the seeds of $D$. senegalense is used for cosmetic products (Neuenschwander et al. 2011). This requires a large collection of seeds in Benin to obtain the fines.

\subsection{Senegalense Product and International Trade}

$D$. senegalense is widely used as service and lumber. In the past, there were some timber exports from West Africa to the United Kingdom and the United States. In the Gambia, D. senegalense is one of the most important timber species. The wood is sold on local Sudanese markets. The fruits are normally 
sold on local markets in West Africa (http://uses.plantnet-project.org/fr/Detarium_senegalense_ (PROTA). It is suitable for parquet flooring, carpentry, interior woodwork and frameworks, mine props, wrought iron, crates and crates, veneers and plywood. They are also used as fuelwood. However, no statistics are available, neither for wood or fruit. The fruits of the species are highly marketed in African countries and especially in Senegal where the fruits of the species are transformed into beverage juice which is widely consumed by rural populations such as Urban seeds (Diop et al., 2011) In Togo, seeds of D. senegalense are heavily traded by local populations, which contribute to socio-economic development and livelihoods (Dangbo et al., 2019).

\subsection{Other Uses of $D$. Senegalense Organs}

The organs and in particular the almonds of $D$. senegalense are used in several other fields than those mentioned above. Seeds and almonds are widely used for the production of pharmaceutical products (Akah et al., 2012). The work of Sowemomo et al. (2011) has shown the chemical composition, antimicrobial activity, close analysis and mineral content of the seed of D. senegalense. The authors in their work have shown the importance of using the seeds of $D$. senegalense in the manufacture of pharmaceutical products. Similarly, the seeds of $D$. senegalense are used in the production of hydrocarbons (Adekunle et al., 2007).

\section{CONCLUSION}

The research on the bibliographical synthesis made it possible to take stock of the work carried out on D. senegalense in the countries of Africa and in Benin in particular. The various studies carried out have shown the important role played by $D$. senegalense through the use of these different organs by rural and urban populations. Information on various aspects such as botanical description, taxonomy, chemical characterization of the organs of the species, taxonomy, phenology and socio-economic importance of the species were provided through the literature search. However, several other aspects of the species have not been the subject of any study. It is therefore essential that future studies be undertaken on aspects such as: ecology, modeling of the ecological niche, conservation status and its silviculture which will allow better knowledge, enhancement and conservation for future generations.

\section{REFERENCES}

[1] Adam, F., Adam, J.C. and Hasselot, N., Intoxication par ingestion de ditakh (Sénégal). Med. Trop. 51, 455458 (1991).

[2] Adekunle A.A., Adebambo O. A., Petroleum Hydrocarbon Utilization by Fungi Isolated From Detarium senegalense (J. F Gmelin) Seeds. Journal of American Science, 3(1), 69-76 (2007).

[3] Akah P. A., Nworu C. S., Mbaoji F. N., Nwabunike I. A., Onyeto C. A., Genus Detarium: Ethnomedicinal, phytochemical and pharmacological profile, Phytopharmacology, 3(2) 367-375 (2012).

[4] Akoègninou, A., van der Burg, W.J. van der Maesen, L.J.G. (Editors), Flore analytique du Bénin. Backhuys Publishers, Leiden, Netherlands. 1034 pp (2006).

[5] Ambé A.A., Les fruits sauvages comestibles des savanes guinéennes de Côte-d'Ivoire : état de la connaissance par une population locale, les Malinké. Biotechnol. Agron. Soc. Environ. 20015 (1), 43-58 (2000).

[6] Arbonnier, M., Arbres, Arbustes et Lianes des Zones Sèches d'Afrique de l'Ouest. $2^{\mathrm{ème}}$ Ed., CIRAD - MNHN, Paris, pp. 9-18, 234-235 (2002).

[7] Arbonnier, M., Trees, shrubs and lianas of West African dry zones. CIRAD, Margraf Publishers Gmbh, MNHN, Paris, France. $573 \mathrm{P}_{\mathrm{P}}$ (2004).

[8] Cavin A.-L., Contribution à la connaissance taxonomique et chimique de fruits africains du genre Detarium (Fabaceae - Caesalpinioideae) : D. microcarpum Guill. et Perr. et des formes comestibles et toxiques de $D$. senegalense J.F. Gmel. Thèse présentée à la Faculté des sciences de l'Université de Genève pour obtenir le grade de Docteur ès sciences, mention sciences pharmaceutiques, 278 p (2007).

[9] Cisse, M., Dieme, O, Diop, N., Dornier, M., Ndiaye, A., Sock, O., Le ditax (D. senegalense J. F. Gmel.) : Principales caractéristiques et utilisations au Sénégal. Fruits, 65(5), 293-306 (2010).

[10] Dangbo F. A., Adjonou K., Kokou K., Blaser J.. The socio-economic contribution of Detarium senegalense seeds to rural livelihoods in Togo (West Africa), International Journal of Biological and Chemical Sciences. 13(3): 1582-1595. DOI: https://dx.doi.org/10.4314/ijbcs.v13i3.30 (2019).

[11] Diop N., Ndiaye A., Cisse M., Dieme O., Dornier M., Sock O., Le ditax (Detarium senegalense J. F. Gmel.): principales caractéristiques et utilisations au Sénégal, Fruits, vol. 65 (5) 293-306. DOI: 10.1051/fruits/2010025 (2010). 
[12] Diop N., Dornier M., Dhuique-Mayer C., Prades A., Munier Pantel S., Pelissier Y., Laroque M., Sock O., Caractérisation d'un fruit sauvage du Sénégal : Le Ditax (Detarium senegalense J.F. Gmel), In : Les plantes du Sahel : usages et enjeux sociaux. Paris : CNRS éd., p. 99-108 (2012)

[13] Diop N., Caractérisation du ditax (Detarium senegalense J.F.Gmel) et étude de sa transformation en nectar. Thèse de Doctorat Université Cheikh Anta Diop de Dakar, 165 Pp (2013).

[14] Diop N., Munier S., Pelissier Y., Boudard F., Mertz C., Lebrun M., Dhuique-Mayer C., Dornier M., Comparison of phenolic and volatile profiles of edible and toxic forms of Detarium senegalense J. F. GMEL. African Journal of Biotechnology, 15(16), 622-632. DOI: 10.5897 / AJB2015.15141 (2016).

[15] Diop N., Caractérisation du ditax (Detarium senegalense J.F.Gmel) et étude de sa transformation en nectar. Thèse de Doctorat Université Cheikh Anta Diop de Dakar, 165 Pp (2013).

[16] El-Kamali, H., Detarium senegalense J.F.Gmel. R. Lemmens, D. Louppe \& A. Oteng-Amoako (Eds.), Protabase. Wageningen, Netherlands: Retrieved from http://database.prota.org/search.htm. (2011).

[17] FAO, Synthèse Régionale de l'Etat des Ressources Génétiques Forestières en Afrique de l'Ouest, 32 Pp (2012).

[18] Home K., Staying Maasai? Pastoral Livelihoods, Diversification and the Role of Wildlife in Development. In Staying Maasai? Livelihoods, Conservation and Development in East African Rangelands, Homewood K, Kristjanson P, Trench P (eds.). 369-408. (2009).

[19] Lawin I. F., Fandohan A. B., Gandji K., Assogbadjo A. E., Ouinsavi C. A. I. N., Cola millenii K. Schum : Etat des connaissances et perspectives de recherche. International Journal of Biological and Chemical Sciences, 12(3), 1494-1515. DOI: https://dx.doi.org/10.4314/ijbcs.v12i3.34 (2018).

[20] Neuenschwander, P., Sinsin, B., Goergen, G., Protection de la Nature en Afrique de l'Ouest: Une Liste Rouge pour le Bénin. Nature Conservation in West Africa:Red List for Benin. International Institute of Tropical Agriculture, Ibadan, Nigeria 36 p (2011).

[21] Sabaly K., Contexte et utilisations locales des fruits de Adansonia digitata et Detarium senegalense au Sine Saloum au Sénégal. Mémoire de Master en Gestion des Ressources Naturelles et Développement Durable au Sénégal, 61 p (2014).

[22] Sanni F. S., Hamza H. G., Onyeyili P. A., Antidiarrheal activity of fractions from aqueous extract of Detarium senegalense. From Botanical to Medical Research, 61(2), 30-40. DOI: 10.1515/hepo-2015-0013 (2015).

[23] Sowemimo A.A., Pendota C., Okoh B., Omotosho T., Idika N., Adekunle A.A., Afaloyan A.J., Chemical composition, antimicrobial activity, proximate analysis and mineral content of the seed of Detarium senegalense J.F. Gmmel. African Journal of Biotechnology Vol. 10(48), 9875-9879. DOI: 10.5897/AJB11.1416 (2011).

[24] Wang Q., Ellis P. R., Simon B., Ross-Murphy, J.S. Grant Reid. A new polysaccharide from a traditional Nigerian plant food: Detarium senegalense Gmelin. Carbohydrate Research 284 (1996) 229-239 (1996).

Citation: Benjamin A.K. Dossa," Knowledge Points and Research Perspectives on Detarium Senegalense, A Vulnerable Species in Benin" International Journal of Research Studies in Biosciences (IJRSB), 8(2), pp 412. DOI: http://dx.doi.org/10.20431/2349-0365.0802002

Copyright: (C) 2020 Authors. This is an open-access article distributed under the terms of the Creative Commons Attribution License, which permits unrestricted use, distribution, and reproduction in any medium, provided the original author and source are credited. 